\title{
Tidal settlement of the intertidal barnacles Chthamalus spp. in SW Portugal: interaction between diel and semi-lunar cycles
}

\author{
David Jacinto $^{1,2, *}$, Teresa Cruz ${ }^{1,2}$ \\ ${ }^{1}$ Laboratório de Ciências do Mar, Universidade de Évora, Apartado 190, 7520-903 Sines, Portugal \\ ${ }^{2}$ Centro de Oceanografia, Faculdade de Ciências da Universidade de Lisboa, 1749-016 Lisbon, Portugal
}

\begin{abstract}
Patterns and processes of tidal settlement (within 1 tidal cycle) of Chthamalus spp. in SW Portugal were investigated during the summer of 2003. Settlement patterns in relation to different periods of the day (night and day) and semi-lunar tidal cycles (spring and neap tides) were assessed using artificial plates deployed in intertidal habitats dominated by C. montagui. Settlement of Chthamalus spp. varied at all temporal and spatial scales considered in this study. A strong interaction between diel and semi-lunar tidal cycles was detected. Settlement was higher during diurnal spring tides (afternoon) than during diurnal and nocturnal neap tides (morning and early night) and was lowest during nocturnal spring tides (late night). In order to investigate putative physical mechanisms of shoreward transport to explain our observations, the tidal variability of several physical variables (wind stress, seawater temperature and temperature stratification) was individually investigated and correlated with settlement. Onshore wind stress was positively correlated with settlement, and exhibited the same night/day and tidal pattern. Onshore wind forcing could be acting as a mechanism promoting intensive larval delivery to the shore in the afternoon (sea breeze) and offshore retention late at night, leading to the high frequency variability patterns observed in barnacle settlement.
\end{abstract}

KEY WORDS: Barnacles $\cdot$ Chthamalus $\cdot$ Settlement $\cdot$ Sea breeze Resale or republication not permitted without written consent of the publisher

\section{INTRODUCTION}

Settlement and recruitment of intertidal barnacles have been extensively documented and described as highly variable at a wide range of both temporal and spatial scales (e.g. Raimondi 1990, Minchinton \& Scheibling 1993, Jenkins et al. 2000, Navarrete \& Wieters 2000). Barnacle recruitment patterns are shaped by phenomena operating at different scales such as processes influencing larval population dynamics (e.g. Pineda 1999), shoreward transport mechanisms (e.g. Shanks 1986, Farrell et al. 1991, Ladah et al. 2005), larval behaviour in the water column and during settlement (e.g. Grosberg 1982, Johnson \& Strathmann 1989), substrate availability (Pineda \& Caswell 1997), micro-hydrodynamic events (Minchinton \& Scheibling
1991, Pineda 2000), cyprid quality (Jarrett \& Pechenik 1997), and post-settlement predation and mortality (e.g. Navarrete \& Wieters 2000).

Chthamalus stellatus (Poli) and C. montagui Southward are very abundant intertidal barnacles in western Europe, overlapping extensively in geographical range from the Atlantic coast of Britain to NW Africa and in the Mediterranean Sea (Crisp et al. 1981). Along the continental SW Portuguese coast, C. montagui is the most abundant intertidal barnacle (Sousa et al. 2000, Range \& Paula 2001), with abundances ca. 3000 times higher than C. stellatus.

Several studies have been published on the reproduction, settlement and recruitment of both European Chthamalus species (see references in O'Riordan et al. 2004). In SW Portugal, recruitment of C. montagui 
occurs throughout the year but reaches a maximum during spring and summer months (O'Riordan et al. 2004). Recruitment intensity of Chthamalus spp. has been shown to vary vertically within the species distribution range and along European coasts at a wide range of spatial (horizontally between $10 \mathrm{~s}$ of $\mathrm{m}$ to $1000 \mathrm{~s}$ of $\mathrm{km}$ ) and temporal (daily, monthly and interannual variability) scales (e.g. Kendall \& Bedford 1987, Power et al. 1999, Range \& Paula 2001, Delany et al. 2003, O'Riordan et al. 2004).

Although in most of its geographical range of distribution there are 2 high tide periods per day in which Chthamalus spp. cyprids can settle to intertidal habitats (semidiurnal tides), few studies have addressed diel variability in settlement patterns (but see Cruz 1999, Cruz et al. 2005). Recently, it has been stressed that lack of temporal resolution $\left(<1\right.$ to $\left.2 \mathrm{~d}^{-1}\right)$ can result in a misinterpretation of the mechanisms that determine the timing and intensity of settlement to intertidal populations (e.g. Pineda 2000, Tapia et al. 2004, T. Cruz et al. unpubl.).

Observations made in SW Portugal on the daily recruitment of Chthamalus spp. during summer 2002 revealed a significant positive correlation between recruitment and phase of the semi-lunar cycle, with highest recruitment observed during spring tides (T. Cruz et al. unpubl.). Previous studies on settlement patterns of Chthamalus spp. conducted along the same coast during spring tides have shown that settlement is higher during diurnal high tides than during nocturnal ones (Cruz 1999, Cruz et al. 2005). From such evidence it was suggested that light could be a physical cue to which cyprids respond positively in order to settle, preferably during daylight, to avoid a first benthic diurnal low tide (diurnal high tide in spring tides is during the afternoon), or that physical processes responsible for shoreward transport of cyprids differed between day and night (Cruz et al. 2005).

Based on these observations, we monitored tidal settlement (within 1 tidal cycle, hereafter called settlement) of Chthamalus spp. to investigate the following models and hypotheses. (1) Light model: If light were a physical cue to which cyprids responded positively (through larval behaviour in the water column and/or at settlement), we predicted higher settlement during diurnal high tides irrespective of the phase of the semilunar cycle (spring or neap tides). (2) Spring tide model: If cyprids were transported shoreward by a mechanism that operates during spring tides, or if the lunar phase influenced settlement through larval behaviour, we predicted higher settlement during spring tides irrespective of day/night cycles. (3) Afternoon model: The timing of high tides in SW Portugal depends on the semi-lunar cycle, with high spring tides occurring in the afternoon and late night, and high neap tides occurring in the morning and early night. Thus, if cyprids were transported shoreward by a mechanism that operates during the afternoon, we predicted a higher settlement during the afternoon (diurnal spring high tides).

In order to investigate putative mechanisms of shoreward transport that might explain our observations, the tidal variability of several physical variables (along-shore [N-S] and cross-shore [E-W] wind stress, seawater temperature and temperature stratification) was individually correlated with settlement and tested in relation to different periods of the day (night and day) and semi-lunar tidal cycles (spring and neap tides).

\section{MATERIALS AND METHODS}

This study was done during the 2003 settlement season (July to September) of Chthamalus spp. on an exposed rocky shore at Praia da Oliveirinha, SW Portugal (Fig. 1).

Tides are semidiurnal and symmetrical with a mean tidal range of approximately $2 \mathrm{~m}$. There is a strong relationship between tidal range and timing of occurrence of the high tides during the $24 \mathrm{~h}$ day cycle: high neap tides occur in the morning and early night, whereas high spring tides occur in the afternoon and late night (Marta-Almeida \& Dubert 2006).

Settlement was defined as the total number of settlers (cyprids and newly metamorphosed juveniles) of

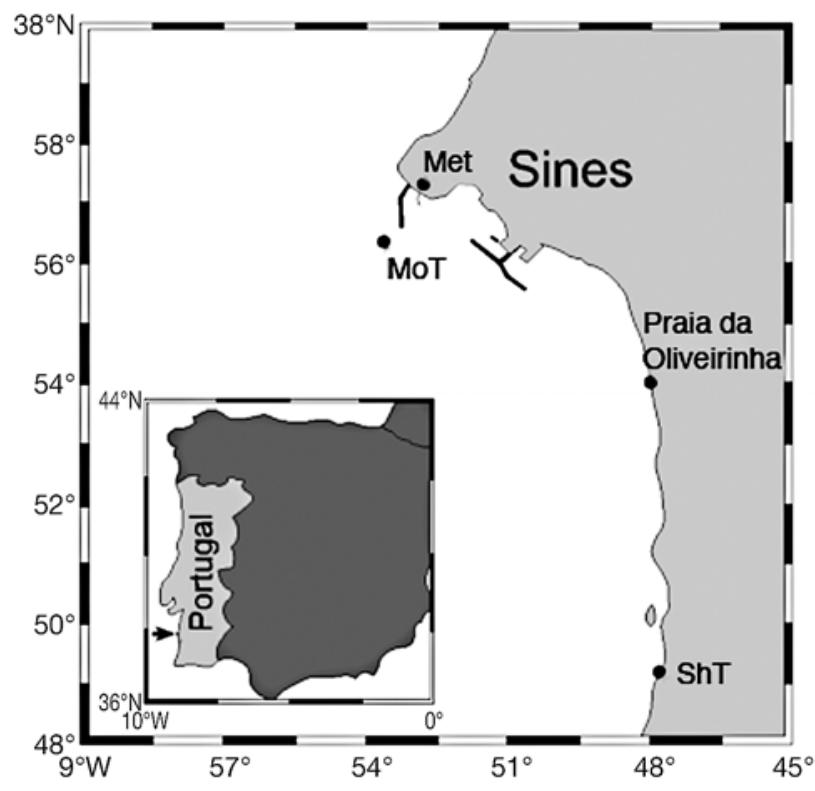

Fig. 1. Location of study shore (Praia da Oliveirinha) in SW Portugal and sites of deployment of data loggers. Met: meteorological station, MoT: moored temperature loggers, ShT: shore temperature logger 
Chthamalus spp. attached to a settlement plate after 1 tidal cycle. We considered 2 different phases of the semi-lunar tidal cycle based on the predicted values of maximum tidal height above hydrographical zero (obtained from tide tables of the Portuguese Instituto Hidrográfico): spring tide (ST, with predicted high tide height $>3.1 \mathrm{~m}$ ); and neap tide (NT, predicted high tide height $<3 \mathrm{~m}$ ). Two daily periods were also considered: diurnal (Diu), when high tide occurred completely during daylight; and nocturnal (Noc), when high tide occurred completely during darkness. High neap tides occurred throughout the morning and early night, whereas high spring tides occurred in the afternoon and late night.

For each phase of the semi-lunar cycle and time of day (STDiu, STNoc, NTDiu and NTNoc), 12 dates were randomly selected within suitable periods. On each date, 2 sites (randomly selected from 20 sites) were sampled with 6 replicate settlement plates each (site area ranged between 4 and $9 \mathrm{~m}^{2}$, distance between sites ranged from 10 to $100 \mathrm{~m}$ ). These sites lay within the dense Chthamalus montagui zone of the mid-shore $(2.1 \pm 0.13 \mathrm{~m}$ [mean $\pm \mathrm{SD}$ ] above hydrographical zero) and have a general slope of $<45^{\circ}$.

Settlement plates consisted of a $5 \times 5 \mathrm{~cm}$ square of grey 3M Safety-Walk ${ }^{\mathrm{TM}}$ Resilient Medium Grade tape glued to a $8 \times 5.5 \times 0.5 \mathrm{~cm}$ PVC plate painted with a mixture of crushed adult barnacles and seawater (200 $\mathrm{g}$ $\mathrm{l}^{-1}$ ) at least $6 \mathrm{~h}$ before the immersion period (because no settlement was observed with untreated new tape in preliminary studies). Plates were attached to the rock surface with a stainless steel screw during low tides, collected after 1 tidal cycle, and carried separately in Petri dishes to the laboratory. Settled cyprids and metamorphs on each plate were counted under a dissecting microscope (subsampling of ten $1 \mathrm{~cm}^{2}$ quadrates was carried out when the total number of settlers was $>300$ per plate) and identified to genus level in the laboratory, using stereoscopic microscopes. We were unable to distinguish cyprids and metamorphs of Chthamalus stellatus and C. montagui using morphological characteristics. Settlement tape was not reutilised.

Sea surface temperature data were gathered every 15 min during the study period by a StowAway TidbiT temperature logger (Onset Computer Corporation) deployed in the low intertidal zone of a nearby shore (ShT, Fig. 1). Also, a mooring cable with 4 temperature loggers (MoT, Fig. 1) was set near the Port of Sines, and water temperature at 5,20,30 and $40 \mathrm{~m}$ above bottom (mab) was recorded every $2 \mathrm{~min}$. For each sampled tide, mean temperature and variance were estimated for a period of 2 and $4 \mathrm{~h}$ centred at high tide peak (ShT and MoT, respectively). Mean and variance of the thermal differential between the 40 and 5 mab depths were also estimated for a period of $4 \mathrm{~h}$ centred at high tide peak. Variance in temperature was interpreted as an indicator of internal motion (T. Cruz et al. unpubl.). Wind data (intensity and direction) were collected every $10 \mathrm{~min}$ at the Port of Sines Meteorological Station (Met, Fig. 1) and mean along-shore and crossshore wind stress were calculated for each sampled tide ( $6 \mathrm{~h}$ period centred at the high tide peak) using the equations described in Jorge da Silva (1992). Additionally, due to the detected significant positive correlation between settlement and cross-shore wind stress (see 'Results'), the mean hourly cross-shore wind stress was calculated for summer 2003. Positive along-shore $(\mathrm{N}-\mathrm{S})$ and cross-shore $(\mathrm{E}-\mathrm{W})$ wind stress values indicate southerly and westerly winds, respectively.

Settlement data were analysed by ANOVA in an experimental design with 4 factors: (1) Lunar cycle (LC), a fixed factor with 2 levels (neap and spring tides); (2) Daily period (DP), a fixed factor with 2 levels (diurnal and nocturnal); (3) Date (Da), a random factor with 12 levels nested in LC and DP; and (4) Site (Si), a random factor with 2 levels nested in LC, DP and Da. Sampling was done with 6 replicate plates. Homogeneity of variance was assessed using Cochran's $C$-test and Student-Newman-Keuls (SNK) tests were used when appropriate (Underwood 1997).

Mean settlement was correlated (Spearman R) with different physical variables measured in each sampled high tide: mean and variance of sea temperature onshore and at different depths nearshore $(5,20,30$ and 40 mab); mean and variance of thermal differential between the 40 and 5 mab depths; mean cross-shore $(\mathrm{E}-\mathrm{W})$ and along-shore $(\mathrm{N}-\mathrm{S})$ wind stress. Variability of physical variables was also analysed using a 2-factor ANOVA (LC and DP, as above) and SNK tests, in which dates were the replicates $(n=12)$.

\section{RESULTS}

Settlement of Chthamalus spp. was highly variable throughout the sampling period (Fig. 2). Mean $\pm \mathrm{SE}$ settlement varied between $1 \pm 0.34$ and $1136 \pm 38.95$ settlers per experimental plate.

Mean \pm SE settlement values during each phase of the semi-lunar cycle and diurnal period were $40 \pm 9.71$ (NTDiu), $32 \pm 14.23$ (NTNoc), $282 \pm 90.30$ (STDiu) and $9 \pm 3.16$ (STNoc) settlers per $25 \mathrm{~cm}^{2}$.

A strong interaction $(\mathrm{p}<0.01)$ between the 2 main effects $(\mathrm{LC} \times \mathrm{DP})$ was detected (Table 1). Significant differences were also detected between dates $(p<$ 0.01 ) and sites ( $p<0.01)$, suggesting variability at both these temporal and spatial scales (Table 1).

Settlement during spring tides was significantly more intense $(p<0.05)$ during the day than at night, whereas during neap tides no significant differences $(p>0.05)$ 


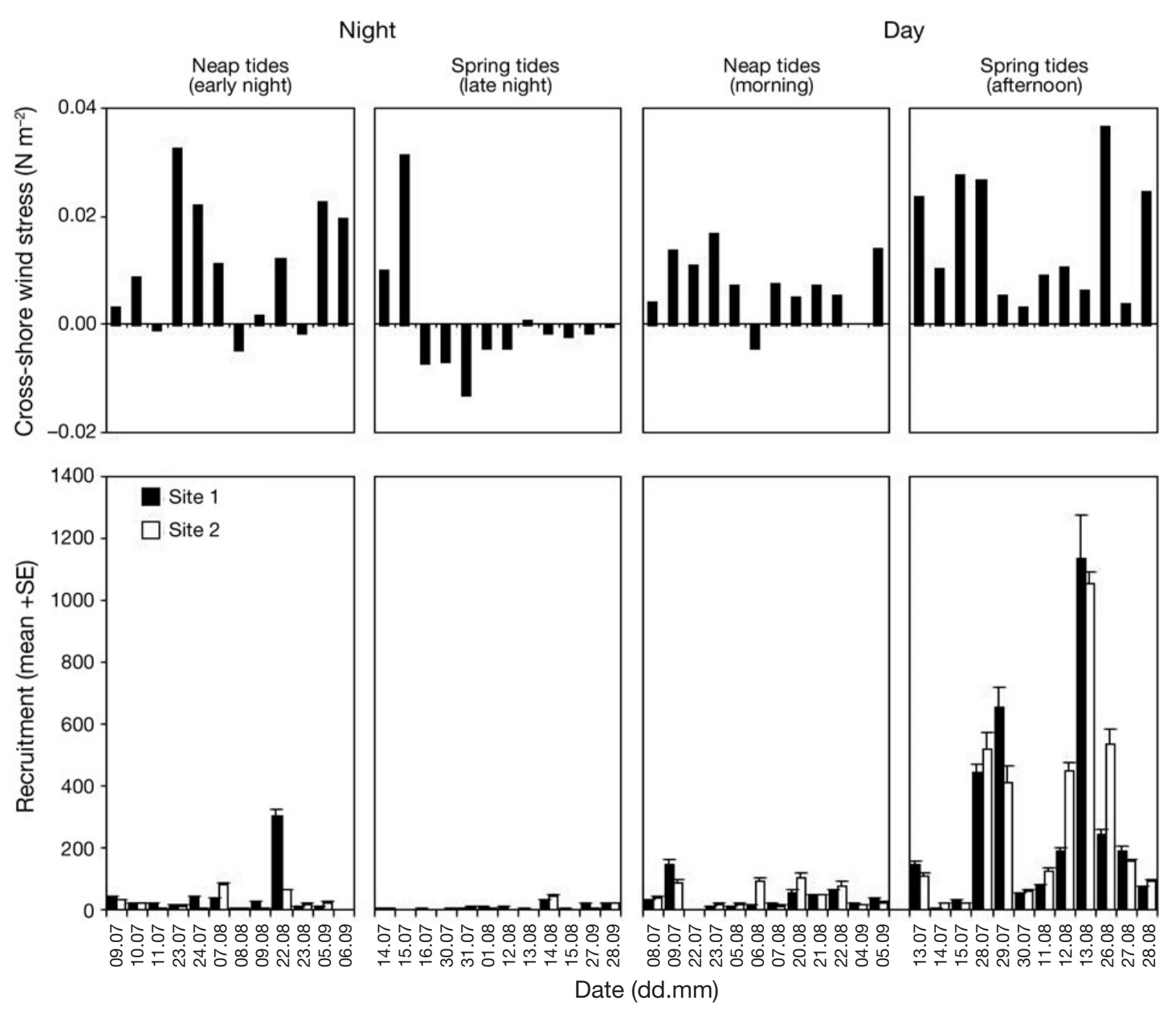

Fig. 2. Mean tidal values of cross-shore (E-W) wind stress (positive values indicate onshore winds) and Chthamalus spp. settlement (mean $+\mathrm{SE}$ ) per $25 \mathrm{~cm}^{2}$ settlement plate $(\mathrm{n}=6)$ at 2 random sites at Praia da Oliveirinha, observed during diurnal and nocturnal high tides in both neap and spring tide cycles in 2003

were detected between diurnal and nocturnal tides (SNK tests for the interaction LC $\times$ DP, Table 1).

Comparing diurnal tides, settlement was more intense during spring tides than during neap tides; in contrast comparing nocturnal tides, settlement was less intense during spring tides than during neap tides ( $\mathrm{p}<0.05$, SNK tests, Table 1).

A significant positive correlation between settlement and cross-shore wind stress was detected $(\mathrm{R}=0.34$; $\mathrm{p}<$ $0.05 ; \mathrm{n}=47$ ). No other correlations between settlement and physical variables were significant. ANOVA results for cross-shore wind stress (Table 2) detected a significant interaction $(\mathrm{p}<0.05)$ between the 2 main effects $(\mathrm{LC} \times \mathrm{DP})$, and SNK tests (Table 2 ) showed that cross-shore wind stress patterns were similar to those of settlement (Table 1).
Westerly winds were more intense during diurnal spring high tides (afternoon) than during diurnal and nocturnal neap high tides (morning and early night) and were the least intense during nocturnal spring tides (late night) (Fig. 2). Mean hourly variation of cross-shore wind stress during the summer (Fig. 3) showed the generality of this pattern during this season. Mean \pm SE cross-shore wind stress values during each phase of the semi-lunar cycle and diurnal period were $0.02 \pm 0.0033$ (STDiu), $0.01 \pm 0.0018$ (NTDiu), $0.01 \pm 0.0034$ (NTNoc) and $0.00 \pm 0.0032$ (STNoc) $\mathrm{N} \mathrm{m}^{-2}$.

ANOVA and SNK tests performed on the other physical variables did not suggest any patterns that could be related to settlement and are not shown here. 
Table 1. ANOVA on number of settlers of Chthamalus spp. at Praia da Oliveirinha in relation to lunar cycle (LC), daily period (DP), date (Da) and site (Si); Transformation: $\ln (x+1)$; Cochran's test: $C=0.05(\mathrm{p}>0.05) . \mathrm{n}=6$. Bold numbers indicate significance $(\mathrm{p}<0.05)$. SNK tests for the interaction term: LC $\times$ DP. $=(p>0.05) ;>$ or $<(p<0.05)$. ST: spring tide, NT: neap tide, Diu: diurnal period, Noc: nocturnal period

\begin{tabular}{|c|c|c|c|c|c|}
\hline $\begin{array}{l}\text { ANOVA } \\
\text { Source of variation }\end{array}$ & df & MS & $F$ & $\mathrm{p}$ & $F$ vs. \\
\hline LC & 1 & 18.82 & 1.25 & & \\
\hline DP & 1 & 504.15 & 33.40 & & \\
\hline $\mathrm{Da}(\mathrm{LC} \times \mathrm{DP})$ & 44 & 15.10 & 7.57 & 0.0000 & $\mathrm{Si}(\mathrm{LC} \times \mathrm{DP} \times \mathrm{Da})$ \\
\hline $\mathrm{Si}(\mathrm{LC} \times \mathrm{DP} \times \mathrm{Da})$ & 48 & 2.00 & 14.48 & 0.0000 & Residual \\
\hline $\mathrm{LC} \times \mathrm{DP}$ & 1 & 262.14 & 17.36 & 0.0001 & $\mathrm{Da}(\mathrm{LC} \times \mathrm{DP})$ \\
\hline Residual & 480 & 0.14 & & & \\
\hline Total & 575 & & & & \\
\hline \multicolumn{6}{|l|}{ SNK tests } \\
\hline $\mathrm{LC}(\mathrm{DP})$ & & \multicolumn{2}{|c|}{$\mathrm{LP}(\mathrm{TC})$} & & \\
\hline Diu: ST > NT & & \multirow{2}{*}{\multicolumn{2}{|c|}{$\begin{array}{l}\text { ST: Diu > Noc } \\
\text { NT: Diu }=\text { Noc }\end{array}$}} & & \\
\hline Noc: $\mathrm{ST}<\mathrm{NT}$ & & & & & \\
\hline
\end{tabular}

Table 2. ANOVA on cross-shore wind stress (tidal means) near the Cape of Sines in relation to lunar cycle (LC) and daily period (DP); Transformation: none; Cochran's test: $C=0.37(\mathrm{p}>0.05) . \mathrm{n}=12$. Bold numbers indicate significance $(p<0.05)$. SNK tests for the interaction term: LC $\times$ DP. $=(p>0.05)_{i}>$ or $<(p<$ 0.05). ST: spring tide, NT: neap tide, Diu: diurnal period, Noc: nocturnal period

\begin{tabular}{|c|c|c|c|c|c|}
\hline $\begin{array}{l}\text { ANOVA } \\
\text { Source of variation }\end{array}$ & $\mathrm{df}$ & MS & $F$ & $\mathrm{p}$ & $F$ vs. \\
\hline $\mathrm{LC}$ & 1 & 0.0000 & 0.30 & & \\
\hline DP & 1 & 0.0006 & 4.56 & & \\
\hline $\mathrm{LC} \times \mathrm{DP}$ & 1 & 0.0013 & 10.25 & 0.0001 & Residual \\
\hline Residual & 44 & 0.0001 & & & \\
\hline Total & 47 & & & & \\
\hline SNK tests & & & & & \\
\hline $\mathrm{LC}(\mathrm{DP})$ & & \multicolumn{2}{|c|}{$\mathrm{DP}(\mathrm{LC})$} & & \\
\hline Diu: ST > NT & & \multirow{2}{*}{\multicolumn{2}{|c|}{$\begin{array}{l}\text { ST: Diu > Noc } \\
\text { NT: } \text { Diu }=\text { Noc }\end{array}$}} & & \\
\hline Noc: $\mathrm{ST}<\mathrm{NT}$ & & & & & \\
\hline
\end{tabular}

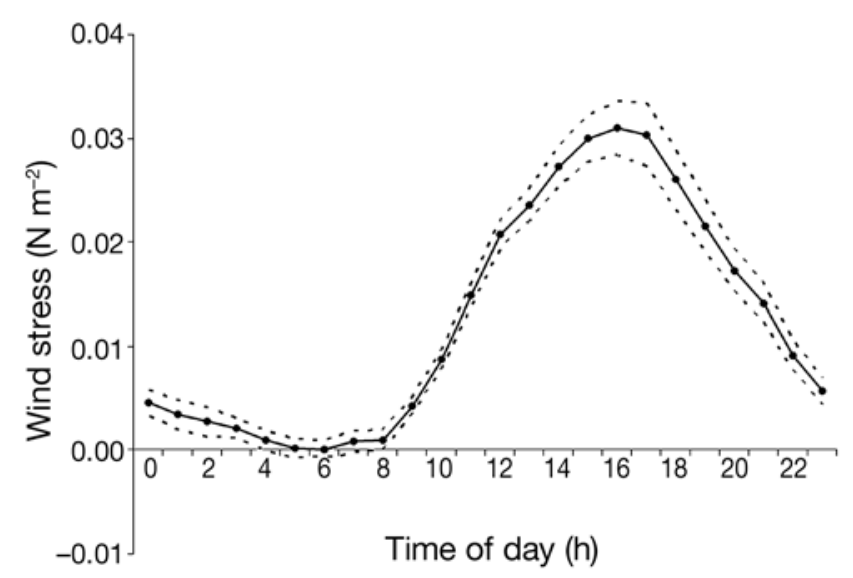

Fig. 3. Mean hourly values and 95\% CIs (dashed lines) for the mean of cross-shore $(\mathrm{E}-\mathrm{W})$ wind stress (positive values indicate shoreward winds) recorded at the Port of Sines meteorological station from 8 July to 6 September

\section{DISCUSSION}

Settlement of Chthamalus spp. varied at all temporal and spatial scales considered in this study. Settlement was higher during diurnal spring tides (afternoon) than during diurnal and nocturnal neap tides (morning and early night) and was lowest during nocturnal spring tides (late night). A strong interaction between night or day and phase of the semi-lunar cycles was detected, determining the intensity of settlement of Chthamalus spp. to the rocky shore in the study area during their main settlement season of 2003.

Previous data on settlement of these species in SW Portugal (Cruz 1999, Cruz et al. 2005) have shown similar patterns during spring tides. It was suggested that settlement behaviour could influence the night/day pattern of settlement of Chthamalus spp. and that light could be a physical cue to which cyprids respond positively in order to settle during the day (Cruz et al. 2005). However, in the present study we extended the observations to neap tide periods, and our results do not support the 'light model' (predicted higher settlement during diurnal high tides irrespective of tidal range) since light did not seem to promote diel variation in barnacle settlement during neap tide periods.

In order to validate the proposed 'spring tide model', we expected higher settlement to occur during spring tides irrespective of period of the day (night or day). Again, the results do not support such a model (even partially), and if there is a larval transport mechanism operating at spring tides, it is interacting with other processes occurring at smaller temporal scales (semidiurnal). Larval behaviour through reverse vertical migrations could interact with transport mechanisms like internal waves or bores which are more frequent during spring tides, promoting such diel variation. However there was no evidence of such a mechanism operating during spring tides in our study area (internal motion variability between tidal cycles was not significant). Also, it has been recently observed that Chthamalus montagui cyprids in northern Portugal were largely restricted to the neuston layer and did not exhibit vertical migration behaviour, unlike its congener C. stellatus (dos Santos et al. 2007). Although in the present study we refer to Chthamalus spp., it is plausible that our results 
only reflect $C$. montagui tidal settlement patterns due to its high abundance in the intertidal habitat.

There seems to be some kind of mechanism(s) promoting higher settlement during the afternoon high tides, supporting our 'afternoon model'. The positive correlation between settlement and onshore wind stress suggests a wind-related transport mechanism responsible for shoreward larval delivery and consequently for the observed settlement patterns. Variability patterns for cross-shore wind stress in relation to the night/day and phase of the semi-lunar cycles are consistent with the observed settlement patterns: settlement was more intense after diurnal afternoon high tides when onshore wind stress was also more intense and less intense during late-night high tides when onshore wind stress was less intense.

During summer, wind patterns along the SW coast of Portugal were very consistent throughout the day, with a strong shoreward sea breeze (indicated by higher values of $\mathrm{E}-\mathrm{W}$ wind stress) forming during the afternoon. Onshore wind forcing could be promoting intensive larval delivery to the shore in the afternoon, and maintaining larvae offshore late at night, thus explaining the variability observed between night and day settlement during spring tides. The daily sea breeze in coastal areas is a mechanism with the potential to transport surface waters and neustonic material onshore (Kaplan et al. 2003, Tapia et al. 2004).

The other mechanism previously proposed as capable of supporting the 'afternoon model' is an adaptive behavioural response of cyprids: settling during the afternoon in order to avoid a first benthic diurnal low tide (Cruz et al. 2005). This was not investigated in the present study.

Although further research is needed on the smallscale variability of physical conditions and larval distribution and abundance in the nearshore water column, results of this study strongly suggest that settlement patterns of Chthamalus spp. in the study area in the summer of 2003 were affected by the daily sea breeze.

The observed temporal variability in settlement among dates was probably due to larger-scale mechanisms (e.g. downwelling) operating in the study region, which can have a profound effect on larval abundance and delivery rates to the shore (Queiroga et al. 2007, T. Cruz et al. unpubl.).

The small-scale spatial variability observed between sites can be associated with hydrodynamics, larval behaviour, predation and spatial heterogeneity of larval distribution in the plankton (Cruz et al. 2005, Ladah et al. 2005).

Our results stress the importance of obtaining frequent observations in order to comprehend the processes that influence the settlement patterns of intertidal barnacles.
Acknowledgements. We thank J. Fernandes and A. Costa for help with the field work, and 2 anonymous reviewers for helpful comments on the manuscript. This project was part of the project ProRecruit (POCTI/1999/BSR/ 36663) funded by the Fundação para a Ciência e Tecnologia (FCT).

\section{LITERATURE CITED}

Crisp DJ, Southward AJ, Southward EC (1981) On the distribution of the intertidal barnacles Chthamalus stellatus, Chthamalus montagui and Euraphia depressa. J Mar Biol Assoc UK 61:359-380

> Cruz T (1999) Settlement patterns of Chthamalus spp. at Praia da Oliveirinha (SW Portugal). Acta Oecol 20:285-287

> Cruz T, Castro JJ, Delany J, McGrath D and others (2005) Tidal rates of settlement of the intertidal barnacles Chthamalus stellatus and Chthamalus montagui in western Europe: the influence of the night/day cycle. J Exp Mar Biol Ecol 318:51-60

Delany J, Myers AA, McGrath D, O'Riordan RM, Power AM (2003) Role of post-settlement mortality and 'supply-side' ecology in setting patterns of intertidal distribution in the chthamalid barnacles Chthamalus montagui and C. stellatus. Mar Ecol Prog Ser 249:207-214

dos Santos A, Santos AMP, Conway DVP (2007) Horizontal and vertical distribution of cirripede cyprid larvae in an upwelling system off the Portuguese coast. Mar Ecol Prog Ser 329:145-155

Farrell TM, Bracher D, Roughgarden J (1991) Cross-shelf transport causes recruitment to intertidal populations in central California. Limnol Oceanogr 36:279-288

Grosberg RK (1982) Intertidal zonation of barnacles: the influence of planktonic zonation of larvae on vertical distribution of adults. Ecology 63:894-899

Jarrett JN, Pechenik JA (1997) Temporal variation in cyprid quality and juvenile growth capacity for an intertidal barnacle. Ecology 78:1262-1265

> Jenkins SR, Åberg P, Cervin G, Coleman RA and others (2000) Spatial and temporal variation in settlement and recruitment of the intertidal barnacle Semibalanus balanoides (L.) (Crustacea: Cirripedia) over a European scale. J Exp Mar Biol Ecol 243:209-225

Johnson LE, Strathmann RR (1989) Settling barnacle larvae avoid substrata previously occupied by a mobile predator. J Exp Mar Biol Ecol 128:87-103

Jorge da Silva A (1992) Dependence of upwelling related circulation on wind forcing and stratification over the Portuguese northern shelf. ICES CM C:17

Kaplan DM, Largier JL, Navarrete SA, Guiñez R, Castilla JC (2003) Large diurnal temperature fluctuations in the nearshore water column. Estuar Coast Shelf Sci 57:385-398

Kendall MA, Bedford ML (1987) Reproduction and recruitment of the barnacle Chthamalus montagui at Aberystwyth (mid-Wales). Mar Ecol Prog Ser 38:305-308

> Ladah LB, Tapia FJ, Pineda J, López M (2005) Spatially heterogeneous, synchronous settlement of Chthamalus spp. larvae in northern Baja California. Mar Ecol Prog Ser 302:177-185

Marta-Almeida M, Dubert J (2006) The structure of tides in the Western Iberian region. Cont Shelf Res 26:385-400

> Minchinton TE, Scheibling RE (1991) The influence of larval supply and settlement on the population structure of barnacles. Ecology 72:1867-1879

Minchinton TE, Scheibling RE (1993) Variations in sampling procedure and frequency affect estimates of recruitment of barnacles. Mar Ecol Prog Ser 99:83-88 
Navarrete SA, Wieters EA (2000) Variation in barnacle recruitment over small scales: larval predation by adults and maintenance of community pattern. J Exp Mar Biol Ecol 253:131-148

O'Riordan RM, Arenas F, Arrontes J, Castro JJ and others (2004) Spatial variation in the recruitment of the intertidal barnacles Chthamalus montagui Southward and Chthamalus stellatus (Poli) (Crustacea: Cirripedia) over an European scale. J Exp Mar Biol Ecol 304:243-264

Pineda J (1999) Circulation and larval distribution in internal tidal bore warm fronts. Limnol Oceanogr 44: 1400-1414

Pineda J (2000) Linking larval settlement to larval transport: assumptions, potentials, and pitfalls. In: Färber-Lorda J (ed) Oceanography of the eastern Pacific, Vol 1. CICESE, Ensenada, p 84-105

Pineda J, Caswell H (1997) Dependence of settlement rate on suitable substrate area. Mar Biol 129:541-548

Power AM, Delany J, Myers AA, O'Riordan RM, McGrath D (1999) Prolonged settlement and prediction of recruitment of two sympatric intertidal Chthamalus species from southwest Ireland. J Mar Biol Assoc UK 79:941-943

Queiroga H, Cruz T, dos Santos A, Dubert J and others (2007) Oceanographic and behavioural processes controlling invertebrate larval dispersal and recruitment in the

Initial editorial responsibility: Howard Browman, Storebø, Norway; Final editorial responsibility: Matthias Seaman, Oldendorf/Luhe, Germany western Iberia upwelling ecosystem. Prog Oceanogr 74: 174-191

Raimondi PT (1990) Patterns, mechanisms, consequences of variability in settlement and recruitment of an intertidal barnacle. Ecol Monogr 60:283-309

Range P, Paula J (2001) Distribution, abundance and recruitment of Chthamalus (Crustacea: Cirripedia) populations along the central coast of Portugal. J Mar Biol Assoc UK 81:461-468

Shanks AL (1986) Tidal periodicity in the daily settlement of intertidal barnacle larvae and an hypothesized mechanism for the cross-shelf transport of cyprids. Biol Bull (Woods Hole) 170:429-440

Sousa EB, Cruz T, Castro JJ (2000) Distribution and abundance of co-occurring chthamalid barnacles Chthamalus montagui and Chthamalus stellatus (Crustacea, Cirripedia) on the southwest coast of Portugal. Hydrobiologia 440:339-345

Tapia FJ, Pineda J, Ocampo-Torres FJ, Fuchs HL, Parnell PE, Montero P, Ramos S (2004) High-frequency observations of wind-forced onshore transport at a coastal site in Baja California. Cont Shelf Res 24:1573-1585

Underwood AJ (1997) Experiments in ecology: their logical design and interpretation using analysis of variance. Cambridge University Press, Cambridge

Submitted: March 8, 2007; Accepted: April 9, 2008

Proofs received from author(s): August 6, 2008 